\section{Summer reading}

Popular science books for the summer scientist.

Let's see: plane ticket, sun block, toothbrush, mp3 player-you are all set for a summer break. Wait, some reading? Well, here comes the dilemma between the latest page-turner and the pile of research article PDFs on your desk. Why not compromise and pack a good popular science book?

Popular science books have been rightfully hailed as a powerful means to boost scientific literacy among the lay public. But as scientists, we too appreciate finding out the story behind discoveries that have now become familiar and learning about other disciplines. Importantly, all scientists can benefit from the inspiring ways that good popular science writers use to communicate science to non-scientists - providing accessible explanations of scientific concepts without compromising their substance and accuracy.

The two indispensable ingredients of a good popular science book - a good story and solid science-are mixed in different proportions by different authors. Practicing scientists who write popular science tend to adopt a tone reminiscent of their lectures, whereas professional science writers use more novelists' tools. Among such variety of styles, and a plethora of topics, something is bound to grab your interest.

Here is an assorted selection of recent books; take it not as an authoritative reference, but rather as an eclectic sampling of our own summer reading lists.

An effective way of humanizing science is to see it as the thread in a person's life, and a few recent biographies are worth noting. In the autobiographical account In Search of Memory (W. W. Norton, 2006), Nobel laureate Eric Kandel retraces his career, mixing personal touches with presentations of various areas of neuroscience. Einstein: his Life and Universe (Simon \& Schuster, 2007) by Walter Isaacson is a new popular account of the physicist's life that is getting good press reviews and follows the more academic biographies published during the Year of Physics. In Francis Crick: Discoverer of the Genetic Code (HarperCollins, 2006), Matt Ridley also paints a human and affectionate portrait of Crick rather than attempting a definitive biography.

The 'mad pursuit' - to use Crick's term-leading to a major scientific discovery, with its share of rivalry and alliances, drama and humor, can make for a gripping read. For example, in A Glow in the Dark (Belknap Harvard, 2005), Vincent Pieribone and David F. Gruber tell the stories surrounding the discovery of green fluo- rescent protein and the revolution it brought to molecular biology. This small book is packed with quirky details and beautiful illustrations. A dose of human psychology may be helpful then, and Daniel Gilbert's Stumbling on Happiness (Knopf, 2006) is in all bookseller windows since winning the UK Royal Society award and being released in paperback in the United States (Vintage Books, 2007).

If this feels too close to home, and you would rather leave the lab and get some adventure in the wild, there are more choices. Robert Sapolsky's A Primate's Memoir (Scribner, 2001) is a personal account of life with a troop of baboons in the Serengeti. Studying the relationship between the level of stress hormones and the animal's position in the social hierarchy, Sapolsky provides insightful descriptions of animal behavior, doubled with reflections about local politics and the daily challenges of a New Yorker living in the bush. A more recent book by Richard Preston, The Wild Trees (Random House, 2007), takes us to the top of California Redwoods with botanists studying the delicate ecosystem of the canopy.

For some of us, with summer come the embarrassing 'simple questions' from those curious friends and relatives-"Hey, you're a scientist, right? Why... [fill in the blank with anything from cosmology to evolution]?". Bill Bryson's acclaimed A Short History of Nearly Everything (Random House, 2003) will provide you with the humorous yet to-the-point answers you need. And Natalie Angier has just published a frustrationborn effort to counter scientific illiteracy. The Canon (Houghton Mifflin, 2007) covers the basics, from probabilities to molecular biology, in Angier's characteristic ornamented prose.

If you are still hesitant, here is a personal favorite. Every year, two collections-The Best American Science Writing (Harper Perennial) and The Best American Science and Nature Writing (Houghton Mifflin)—compile science articles published in popular magazines. The diverse selection of styles and topics is made each year by a guest editor, who is chosen among today's best science writers. Either 2006 edition offers great short reads to explore the genre.

Hoping that you will be hooked, we have also posted a selection of timeless classics well worth a read on methagora. But that is for when you get back, tanned and relaxed! 